\title{
Intracellular accumulation of amyloid-beta - a predictor for synaptic dysfunction and neuron loss in Alzheimer's disease
}

\section{Thomas A. Bayer and Oliver Wirths* \\ Division of Molecular Psychiatry and Alzheimer Ph.D. Graduate School, Department of Psychiatry, University of Göttingen, Göttingen, Germany}

\section{Edited by:}

P. Hemachandra Reddy,

Oregen Health and Science University,

USA

Reviewed by:

Asgar Zaheer,

University of lowa Hospitals and

Clinics, USA

H. K. Anandatheerthavarada,

University of Pennsylvania, USA

Salvatore Oddo,

The University of Texas Health Science

Center, USA

P. Hemachandra Reddy,

Oregen Health and Science University,

USA

\section{${ }^{*}$ Correspondence:}

Oliver Wirths, Division of Molecular

Psychiatry, Department of Psychiatry,

University of Göttingen,

von-Siebold-Street 5, 37075 Göttingen,

Germany.

e-mail: owirths@gwdg.de

\section{INTRODUCTION}

Alzheimer's disease $(\mathrm{AD})$ represents the most frequent form of dementia and is characterized by two major neuropathological hallmarks: (i) extracellular plaques composed of the 40-42 residues A $\beta$ peptide (Hardy and Allsop, 1991) and (ii) neurofibrillary tangles, consisting of abnormal phosphorylated Tau protein (Braak and Braak, 1991). There is increasing evidence that, in addition to the well-known extracellular amyloid deposition in the parenchyma, $A \beta$ peptides accumulate inside neurons (Gouras et al., 2000). It has been hypothesized that this initial accumulation is one of the earliest pathological events, thereby triggering the cascade leading to neurodegeneration (Wirths et al., 2004). Since their initial generation in the mid 1990s, transgenic mice have been proven to represent valuable model systems reflecting various pathological subfields of AD like plaque deposition, inflammatory changes or behavioral abnormalities (reviewed in Games et al., 2006; Duyckaerts et al., 2008). In the present review, we summarize the current achievements of modeling early intraneuronal A $\beta$ accumulation in transgenic mice with their resulting pathological consequences. Of special importance will be the critical discussion of this observation, because in all mouse models in which marked neuron loss has been so far reported, this was preceded by considerable amounts of intraneuronal $A \beta$ peptides. In the present short review, we will discuss the view that intraneuronal accumulation of $\mathrm{A} \beta$ peptides leads to traffic problems accompanied by early axonopathy, synaptic loss and neuron death. Extracellular plaque pathology, as we and others believe, has a weaker impact on neurodegeneration.

\section{PROCESSING OF THE AMYLOID PRECURSOR PROTEIN GENERATES A $\beta$ PEPTIDES}

The generation of $A \beta$ peptides is due to enzymatic cleavage of the larger amyloid precursor protein (APP), which represents a type I membrane protein with a large $\mathrm{N}$-terminal ectodomain and a short intracellular C-terminal domain. Alternative splicing of APP yields eight isoforms with lengths of 677-770 amino acid residues, of which APP695 is the primary transcript in neurons (Bayer et al., 2001). APP can be processed by two different pathways: (i) nonamyloidogenic processing: Cleavage by $\alpha$-secretase within the $A \beta$ domain releases a secreted form of APP ( $\mathrm{sAPP} \alpha)$, thereby precluding the generation of toxic $A \beta$ peptides. Different members of the ADAM protein family (a disintegrin and metalloprotease) have been demonstrated to possess $\alpha$-secretase activity (Buxbaum et al., 1998; Lammich et al., 1999). (ii) Amyloidogenic processing: This APP processing pathway results in cleavage at the $\beta$-secretase site, liberating also a secreted form of APP ( $\mathrm{SAPP} \beta)$, and leading to the generation of a membrane-associated $\mathrm{C}$-terminal fragment named C99. The $\beta$-site APP cleaving enzyme 1 (BACE) belongs to the family of aspartyl proteases and has been identified simultaneously by different research groups (Hussain et al., 1999; Sinha et al., 1999; Vassar et al., 1999; Yan et al., 1999). Subsequent cleavage of C99 by $\gamma$-secretase activity results in the generation of $40-42$ residue A $\beta$ peptides, as well as a short intracellular APP fragment named AICD. It has been shown that $\gamma$-secretase consists of a complex of different proteins including presenilin-1 (PS1) or presenilin-2 (PS2), as well as nicastrin, anterior pharynx defective (APH-1) and presenilin enhancer 2 (PEN-2) (reviewed in Selkoe and Wolfe, 2007). 
Mutations in either APP or in the presenilin genes have been linked to familiar, early onset forms of AD. These cases represent only a minor portion $(\sim 5 \%)$, whereas the vast majority of AD cases develop sporadically. Most of the reported APP mutations are located near the secretase cleavage sites and lead to an overproduction of $A \beta$ peptides. Some of these mutations (e.g. the Austrian mutation T714I), as well as a couple of PS1 mutations have a drastic effect on the $A \beta 42 / A \beta 40$ ratio by strongly increasing $\mathrm{A} \beta 42$ production with concomitant suppression of $\mathrm{A} \beta 40$ secretion (Kumar-Singh et al., 2000; Wolfe, 2007).

\section{SYNAPTIC PATHOLOGY IN ALZHEIMER'S DISEASE}

The classical amyloid cascade hypothesis supports the idea that increased $A \beta$ production and extracellular accumulation leads to progressive synaptic and neuronal injury ending up in widespread neuronal dysfunction and dementia (Hardy and Selkoe, 2002). However, despite of intense research efforts during the last 20 years, the early molecular events leading to AD are still not clear. It has been shown that the loss of synaptic terminals correlates better with cognitive decline than extracellular plaque load or loss of neurons, leading to the concept that losing synapses is one of the key events leading to cognitive dysfunction in AD (Terry et al., 1991). Neuropathological analyses confirmed a loss of synaptophysinimmunoreactive synaptic terminals, e.g., in the outer molecular layer of the dentate gyrus in AD (Masliah et al., 1994), as well as a $25 \%$ loss of synaptophysin-immunoreactivity already in mild AD cases in the frontal cortex (Masliah et al., 2001). Recently, it has been reported that mild $\mathrm{AD}$ patients had fewer synapses in the stratum radiatum of the CA1 subfield (55\%) than control patients and that patients suffering from mild cognitive impairment (MCI) had a mean synaptic value which was $18 \%$ lower than in the control group without cognitive impairment. These results further strengthen the hypothesis that synaptic loss is one of the earliest events in $\mathrm{AD}$ pathology and support the concept that MCI is a transitional stage between no cognitive impairment and mild AD (Scheff et al., 2007).

\section{INTRANEURONAL AB ACCUMULATION IN AD}

The occurrence and relevance of intraneuronal $A \beta$ accumulations in $\mathrm{AD}$ have been a matter of controversial scientific debate. First reports showing that $A \beta$ is initially deposited in neurons before occurring in the extracellular space date back roughly 20 years (Masters et al., 1985; Grundke-Iqbal et al., 1989). More recently it has been shown that neurons in $\mathrm{AD}$-vulnerable regions accumulate $A \beta 42$ and it has been further suggested that this accumulation precedes neurofibrillary tangle formation and extracellular $\mathrm{A} \beta$ deposition (Gouras et al., 2000). Consecutively a variety of reports has been published demonstrating $\mathrm{A} \beta$ in neurons of $\mathrm{AD}$ (Mochizuki et al., 2000; D'Andrea et al., 2001, 2002; Fernandez-Vizarra et al., 2004) and Down syndrome (DS) patients (Gyure et al., 2001; Busciglio et al., 2002; Mori et al., 2002). On the contrary, a more recent study described intracellular $A \beta$ immunoreactivity during the entire life span in control subjects and DS patients, leading to the suggestion that this represents rather a feature of normal neuronal metabolism than a pathological alteration. As the authors found the strongest intraneuronal $A \beta$ in brain structures that are not highly vulnerable to $\mathrm{AD}$-associated changes, they believe that intraneuronal $A \beta$ immunoreactivity is not a predictor of brain amyloidosis or neurofibrillary degeneration (Wegiel et al., 2007). Aoki and colleagues investigated whether $A \beta$ levels are changed in CA1 pyramidal neurons of AD hippocampus, using laser capture microdissection to isolate neurons and enzyme-linked immunosorbent assay for quantification. The results showed increased A $\beta 42$ levels and an elevated $A \beta 42 / A \beta 40$ ratio in neurons from sporadic as well as from familial AD cases, whereas $A \beta 40$ levels remained unaffected (Aoki et al., 2008). Recent reports have shown that modifications of the staining method have crucial influence on the detection of $\mathrm{A} \beta$ peptides in neurons. Whereas pretreatment of $\mathrm{AD}$ tissues using formic acid enhances the immunological detection of extracellular plaques, it might have an opposing effect on intracellular $\mathrm{A} \beta$ peptides. Heat-induced antigen retrieval has been proposed to have the most significant effect, whereas enzymatic treatment alone is not sufficient (D'Andrea et al., 2003; Ohyagi et al., 2007). Fixation might also be an important point, as intracellular $\mathrm{A} \beta$ detection in mice is well-documented (Wirths et al., 2001, 2002; Blanchard et al., 2003; Oddo et al., 2003; Casas et al., 2004; Lord et al., 2006; Oakley et al., 2006; Knobloch et al., 2007b), however, these tissues are usually fixed by transcardial perfusion in a narrow time frame, whereas human material as a general rule is subjected to much longer post-mortem intervals.

\section{ALTERNATE SOURCES OF INTRANEURONAL A $\beta$}

A second mechanism that contributes to intracellular $A \beta$ accumulation is uptake from the extracellular space, in addition to intraneuronal $A \beta$ production. It has been previously shown that cells that were treated with synthetic $A \beta$ peptides, selectively accumulate $A \beta 42$ and that this internalization could be prevented under conditions that block endocytosis (Knauer et al., 1992). Uptake of A $\beta 1-42$ is enhanced by integrin antagonists and blocked by NMDA receptor antagonists (Bi et al., 2002). Cultured hippocampal slices were exposed to $A \beta 1-42$ for 6 days in the presence or absence of soluble Gly-Arg-Gly-Asp-Ser-Pro, a peptide antagonist of Arg-Gly-Asp (RGD)-binding integrins, or the disintegrin echistatin. $A \beta$ uptake, as assessed with immunocytochemistry, occurred in $42 \%$ of the slices incubated with $\mathrm{A} \beta$ peptide alone but in more than $80 \%$ of the slices co-treated with integrin antagonists. The selective NMDA receptor antagonist D-(-)-2-amino-5-phosphonovalerate completely blocked internalization of $A \beta$ (Bi et al., 2002). On the subcellular level, internalized $A \beta 42$ peptides seem to accumulate especially in the endosomal/lysosomal system which leads to lysosomal permeability and membrane damage (Yang et al., 1998; Ditaranto et al., 2001). One possible internalization mechanism might be cell-surface receptor-mediated uptake via the $\alpha 7$ nicotinic acetylcholine receptor (Nagele et al., 2002), but also passive diffusion of extracellular $\mathrm{A} \beta$ through the plasma membrane has been suggested (Li et al., 2007).

A selective $A \beta 42$ uptake was revealed in the CA1 subfield of rat organotypic slice cultures, whereas other hippocampal regions like CA3 and dentate gyrus remained almost unaffected (Bahr et al., 1998). Primary neurons from APP transgenic Tg2576 mice accumulate $A \beta$ peptides and have been shown to undergo selective reductions in synaptic levels of PSD-95 and the glutamate receptor subunit GluR1 compared to the wild-type situation (Almeida et al., 2005). As A $\beta$ has been implicated in the depression of AMPA 
receptor currents, thereby regulating synaptic activity (Kamenetz et al., 2003), reduced levels of GluR1 provide a molecular basis for A $\beta$-induced AMPA current alterations (Almeida et al., 2005). Wang et al. reported that $A \beta 1-42$ inhibits alpha7nAChR-dependent calcium activation and acetylcholine release, two processes critically involved in memory and cognitive functions (Wang et al., 2000). Internalization of A $\beta 1-42$ may be facilitated by the high-affinity binding to the alpha7 receptor on neuronal cell surfaces, followed by endocytosis of the resulting complex (Nagele et al., 2002). Dziewczapolski et al. have shown that, despite the presence of high amounts of APP and amyloid deposits, deleting the alpha7nAChR subunit in PDAPP mice leads to a protection from the dysfunction in synaptic integrity (pathology and plasticity) and learning and memory behavior. APP/alpha7nAChR KO mice express APP and $\mathrm{A} \beta$ at levels similar to APP mice, however they were able to solve a cognitive challenge such as the Morris water maze test significantly better than APP single transgenic mice, with performances comparable to control groups. Moreover, deleting the alpha7nAChR subunit protected the brain from loss of the synaptic markers synaptophysin and MAP2, reduced the gliosis, and preserved the capacity to elicit long-term potentiation (LTP) which is deficient in the single transgenic APP mice used. These results are consistent with the hypothesis that the alpha7nAChR plays a role in AD and suggest that interrupting alpha7nAChR function could be beneficial in the treatment of AD (Dziewczapolski et al., 2009).

\section{MITOCHONDRIAL DYSFUNCTION AND INTRANEURONAL A $\beta$}

Reviewed in detail, there is increasing evidence that oxidative damage, induced by $A \beta$, is associated with mitochondrial dysfunction early in AD development (Reddy and Beal, 2008). A $\beta$ binds to alcohol dehydrogenase $(\mathrm{ABAD})$ demonstrating a direct molecular link from $A \beta$ to mitochondrial toxicity in $\mathrm{AD}$ patients and transgenic mice. The crystal structure of $A \beta$-bound ABAD showed substantial deformation of the active site inhibiting nicotinamide adenine dinucleotide (NAD) binding (Lustbader et al., 2004). Of interest, intracellular $A \beta$ is present in mitochondria in brains from APP transgenic mice and $\mathrm{AD}$ patients. It has been shown that $\mathrm{A} \beta$ progressively accumulated in mitochondria and was associated with diminished enzymatic activity of respiratory chain complexes (III and IV) and a reduction in the rate of oxygen consumption (Caspersen et al., 2005). In addition, cytochrome $c$ oxidase activity was found to be decreased in Tg2576 mice, suggesting that mutant APP and/or soluble A $\beta$ impair mitochondrial metabolism in AD development and progression (Manczak et al., 2006).

Treatment of cultured hippocampal neurons with $A \beta$ resulted in rapid and severe impairment of mitochondrial transport without inducing apparent cell death and significant morphological changes, whereas stimulation of protein kinase A (PKA) by forskolin, cAMP analogs or neuropeptides effectively alleviated the impairment. In addition, $A \beta$ inhibited mitochondrial transport by acting through glycogen synthase kinase $3 \beta$ (GSK3 $\beta$ ) (Rui et al., 2006). Mitochondrial damage such as reduced mitochondrial membrane potential and ATP levels have been detected in the brains from APP and APP/PS1 transgenic mice before the onset of plaques arguing for a role of intracellular and/or soluble $\mathrm{A} \beta$ on mitochondrial dysfunction (Eckert et al., 2008). Results from rat mitochondria demonstrated that $A \beta$ is transported into mitochondria via the translocase of the outer membrane (TOM) machinery. Subcellular fractionation studies following the import experiments revealed $\mathrm{A} \beta$ association with the inner membrane fraction, and immunoelectron microscopy after import showed localization of $A \beta$ to mitochondrial cristae. In addition, it could be demonstrated that extracellularly applied $\mathrm{A} \beta$ was taken up by human neuroblastoma cells which then colocalized with mitochondrial markers (Hansson Petersen et al., 2008). It has also been reported that the receptor for advanced glycation end products (RAGE) contributes to transport of $A \beta$ from the cell surface to the intracellular space. Mouse cortical neurons were treated with extracellular human $A \beta$ showing detectable $A \beta$ intracellularly in the cytosol and mitochondria by confocal and immunogold electron microscopy. Intraneuronal co-localization of $A \beta$ and RAGE was also observed in the hippocampus of APP transgenic mice (Takuma et al., 2009). Very recently, a drosophila model was described in which overexpression of $A \beta$, resulting in $A \beta$ accumulation in the soma and axons of neurons, leads to a variety of mitochondrial abnormalities including depletion of presynaptic and axonal mitochondria, a decrease in axonal transport of mitochondria, as well as changes in mitochondrial size and number (Zhao et al., 2010).

\section{A $B$ OLIGOMERS AND SYNAPTIC DYSFUNCTION}

$A \beta$ protein assembly and oligomer formation has been reviewed extensively in the past (for example, Klein et al., 2001; Klein, 2002; Roychaudhuri et al., 2009) and is therefore not a focus of the present review. The formation of $A \beta$ oligomers has been repeatedly reported to contribute significantly to the pathophysiological alterations underlying $\mathrm{AD}$ and it has been shown that soluble oligomeric $\mathrm{A} \beta 42$ and not plaque-associated $\mathrm{A} \beta$ correlates best with cognitive dysfunction (McLean et al., 1999; Naslund et al., 2000). Oligomers are formed preferentially intracellularly within neuronal processes and synapses rather than within the extracellular space (Walsh et al., 2000; Takahashi et al., 2004) and have been demonstrated to cause synaptic alterations (Lacor et al., 2004, 2007). These oligomers have been previously demonstrated to inhibit hippocampal LTP and disrupt synaptic plasticity (Lambert et al., 1998; Walsh et al., 2002) and have been shown to originate from intraneuronal rather than extracellular dimerization (Walsh et al., 2000). By the use of antibodies raised against synthetic $A \beta$ oligomer assemblies, these oligomers or $\mathrm{A} \beta$-derived diffusible ligands (ADDLs) have detected in up to 70-fold higher concentrations in $\mathrm{AD}$ compared to control brains (Gong et al., 2003). However, as these oligomers normally occur both inside neurons as well as in a secreted form, it is difficult to attribute the toxic actions to one of the different entities. In addition, it has been shown that $A \beta$-derived oligomers specifically bind to pyramidal neurons, promoting a rapid decrease in the membrane expression levels of memory-related receptors like NMDA or EphB2 (Lacor et al., 2007). In hippocampal neuron cultures, ADDLs stimulated the excessive formation of reactive oxygen species (ROS) through a mechanism requiring NMDA receptor activation. Interestingly, the memory-preserving drug memantine, which represents a NMDA receptor antagonist, completely protected against these toxic effects, indicating that ADDLs bind to NMDA receptors and trigger neuronal damage through receptor-dependent calcium influx (De Felice et al., 2007). In addition, concentrations of soluble $A \beta$ clearly distinguished healthy 
controls from $\mathrm{AD}$ patients and represent a strong inverse correlate of synapse loss (Lue et al., 1999; McLean et al., 1999). In addition to ADDLs, globular $\mathrm{A} \beta$ species called globulomers have been found to be toxic (Barghorn et al., 2005) and suppressed spontaneous synaptic activity by inhibition of P/Q-type calcium currents (Nimmrich et al., 2008).

\section{TRANSGENIC AD MOUSE MODELS WITH INTRANEURONAL AB ACCUMULATION AND SYNAPTIC PATHOLOGY}

The data in $A D$ mouse models regarding intraneuronal $A \beta$ are much more consistent and an increasing consensus can be observed during the past years. Intraneuronal $A \beta$ was first reported in familial PS1 transgenic mice that also showed neurodegeneration without the formation of plaque pathology (Chui et al., 1999). During the last years, intraneuronal accumulation has been reported in several mouse models including $\mathrm{APP}_{\mathrm{SDL}} \mathrm{PS}_{\mathrm{M} 146 \mathrm{~L}}$ (Wirths et al., 2001), $\mathrm{APP}_{\mathrm{SL}} \mathrm{PS1}_{\mathrm{M} 146 \mathrm{~L}}$ (Wirths et al., 2002), Tg2576 (Takahashi et al., 2002), 3xTg-AD (Oddo et al., 2003), 5xFAD (Oakley et al., 2006), APP Arc (Lord et al., 2006; Knobloch et al., 2007b), APP T714I $_{\text {mice (Van }}$

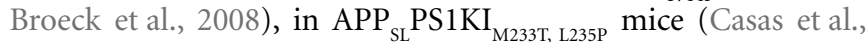
2004) in which it was recently shown to correlate with neuron loss (Christensen et al., 2008a,b; Breyhan et al., 2009), as well as in TBA2 mice expressing pyroglutamate modified $\mathrm{A} \beta 3-42$ (Wirths et al., 2009). These models differ in a variety of parameters including the expressed APP isoform, the APP mutations included, the expression level of APP, the promoter construct used to drive expression of the transgene, as well as in the fact whether they are single or multitransgenic (co-expression of Presenilin-1 or Tau) (see Table 1).

Early intraneuronal $A \beta$ accumulation preceding extracellular amyloid plaque pathology has been detected in a model expressing APP751 with the Swedish and London mutations $\left(\mathrm{APP}_{751 \mathrm{LL}}\right)$, in combination with transgenic mutant human PS1 with the M146L mutation expressed under the control of the HMG-CoAreductase promoter. Strong $A \beta$ staining was identified in somatodendritic compartments of neurons in subiculum, CA1 region of the hippocampus, as well as in cortical areas already in young mice (Wirths et al., 2002; Blanchard et al., 2003). It has been shown that with incremental extracellular pathology an attenuated intraneuronal $\mathrm{A} \beta$ immunoreactivity was noted (Wirths et al., 2002; Langui et al., 2004). This finding corroborates an observation in DS patients, where consistently strong cellular $A \beta$ staining was reported in young patients, with a progressive decline paralleling deposition and maturation of extracellular amyloid plaques (Mori et al., 2002). A detailed stereological analysis revealed that both the single transgenic $\mathrm{APP}_{751 \mathrm{SL}}$ mice and PS1M146L mice showed an age-related loss of synaptophysin-immunoreactive presynaptic boutons (SIPBs) within the stratum radiatum. Importantly, $\mathrm{APP}_{751 \mathrm{LL}} / \mathrm{PS}_{\mathrm{M} 146 \mathrm{~L}}$ mice displayed the most severe age-related SIPB loss within stratum moleculare, stratum lacunosum and stratum radiatum, even in regions free of extracellular $A \beta$ deposits (Rutten et al., 2005).

Analysis of the subcellular localization of $A \beta$ peptides by means of double-fluorescence experiments in these mice revealed that intracellular $A \beta$ colocalized with lysosomal markers and less frequently with markers of the trans-Golgi network (TGN). Using electron microscopy, $\mathrm{A} \beta$ has been detected in the lumen of multivesicular bodies (MVBs) (Langui et al., 2004), corroborating an earlier report in Tg2576 mice showing that $\mathrm{A} \beta 42$ is localized predominantly to MVBs within pre- and postsynaptic compartments (Takahashi et al., 2002). In Tg2576 mice an altered synaptic morphology has been recognized which preceded extracellular amyloid deposition (Takahashi et al., 2002) and it has been shown in a subsequent report that $\mathrm{A} \beta 42$ aggregates into oligomers within endosomal vesicles, as well as in neuronal processes (Takahashi et al., 2004). This is particularly interesting as it has been hypothesized that $A \beta$ oligomers have a significant impact on the pathological alterations underlying memory deficits in $\mathrm{AD}$ patients, as they have been demonstrated to disrupt synaptic plasticity and to inhibit hippocampal LTP (Lambert et al., 1998; Walsh et al., 2002). Using stereology at the light and electron microscopy level, synapse density was assessed in Tg2576 mice in hippocampus and entorhinal cortex. No overall decrease in the density of synaptophysin-positive boutons could

Table 1 | Overview of transgenic AD mouse models in which intraneuronal A $\boldsymbol{\beta}$ accumulation has been reported. In addition, information on extracellular plaque onset, neuron loss and synaptic pathology are given (n.a., not analyzed).

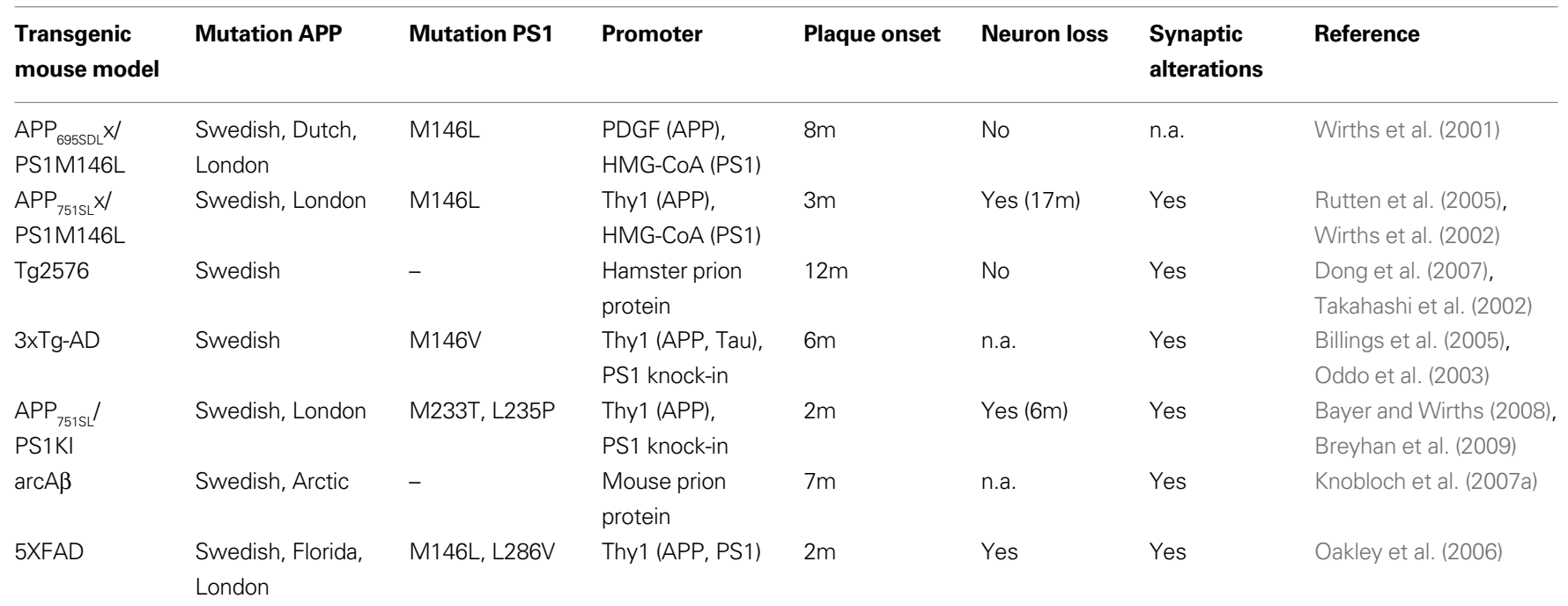


be found on the light microscopy level, however, using electron microscopy, an overall decreases in synapse density in the outer molecular layer of the dentate gyrus at both 6-9 and 15-18 months of age, and in Layers II and III of the entorhinal cortex at 15-18 months of age was detected (Dong et al., 2007).

A further interesting model expresses APP with the Swedish and London mutations on a homozygous mutant PS1 knock-in background (APP/PS1KI). These animals show early extracellular amyloid deposition at the age of 2 months, which is preceded by strong intraneuronal $\mathrm{A} \beta$ accumulation in hippocampus, cortex and motor neurons of the spinal cord (Figures 1E,F). Staining with the $\beta$-sheet binding dye Thioflavin-S indicated that the intraneuronal $\mathrm{A} \beta$ is aggregated and is present in the form of $\beta$-pleated sheets. Further pathological features include severe axonal degeneration, as well as motor and cognitive deficits starting at the age of 6 months (Casas et al., 2004; Wirths et al., 2007, 2008; Bayer and Wirths, 2008). At this time point also synaptic alterations became evident. The levels of the postsynaptic marker protein PSD-95 were significantly decreased in whole brain lysates. In addition, analysis of synaptosome-enriched fractions revealed a significant decrease in the levels of the presynaptic markers SNAP25 and clathrin-light chain, as well as of the postsynaptic marker PSD-95. Recordings of field

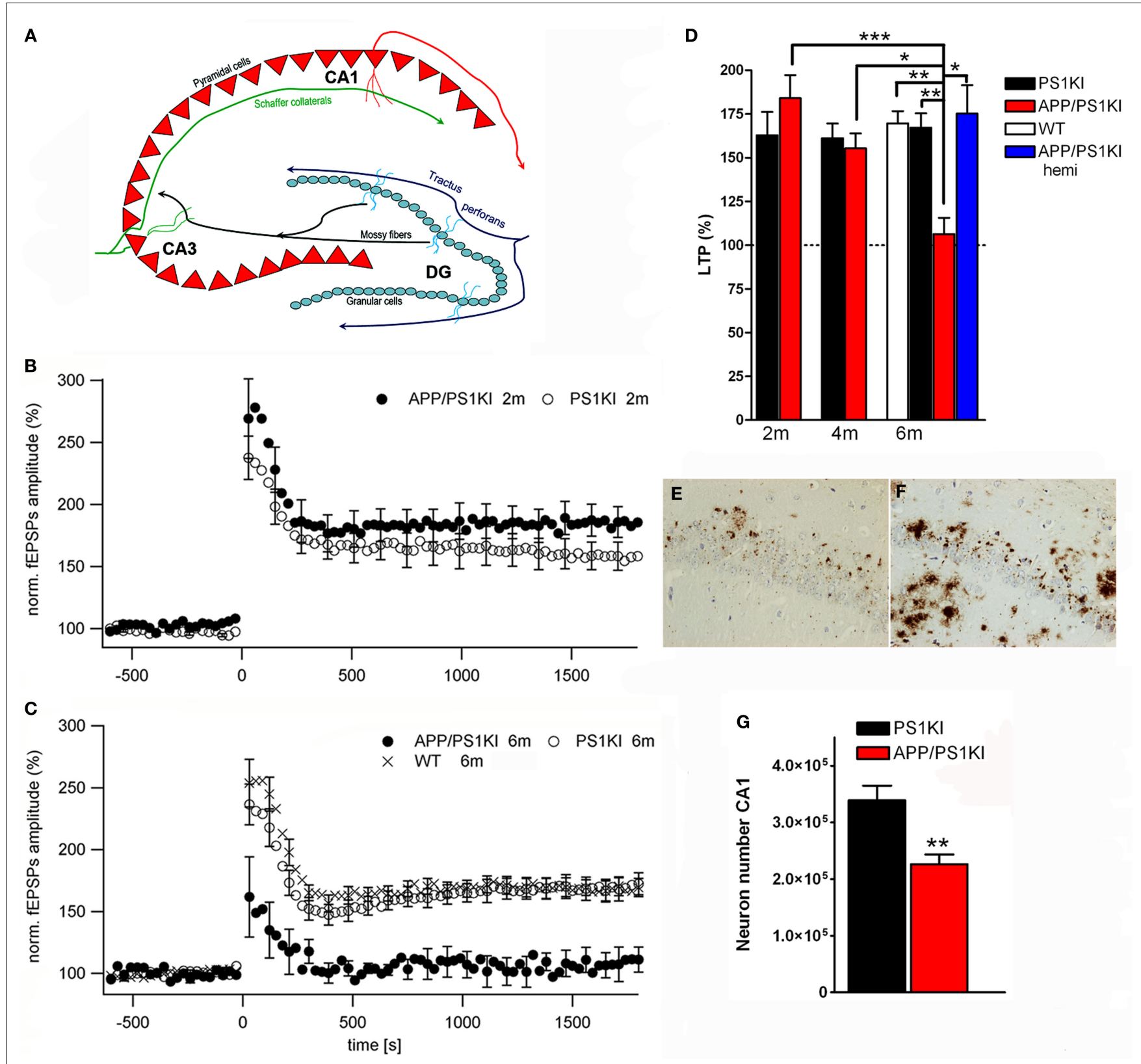

FIGURE 1 | Intraneuronal A $\beta$ accumulation and impaired LTP in APP/PS1KI mice. Schematic drawing of the hippocampus (A). At 6 months of age deficits in synaptic transmission in the form of altered LTP are detected in APP/PS1 KI mice
(B-D). Intraneuronal accumulation of $A \beta$ peptides occurs already at 2 months of age in the CA1 region of the hippocampus (E) and precedes neuron loss which becomes evident at 6 months of age $(\mathbf{F}, \mathbf{G})$. 
excitatory postsynaptic potentials (fEPSPs) disclosed a significant reduction of fEPSPs in 6-month-old APP/PS1KI compared to PS1KI or wild-type mice (Figures 1A-D). Short-term synaptic plasticity was also affected, as 6-month-old APP/PS1KI mice disclosed unaltered paired pulse facilitation (PPF) ratios before and after LTP, in contrast to PS1KI and WT mice, which showed the expected lower PPF ratios after LTP induction (Breyhan et al., 2009).

Mice expressing human APP with the Arctic mutation (E693G) have been recently developed (Lord et al., 2006; Knobloch et al., 2007b). This mutation is particularly interesting as it has been demonstrated that protofibrils are produced at a much higher rate and in larger quantities than wild-type $\mathrm{A} \beta$ (Nilsberth et al., 2001). The available mouse models express APP with both the Swedish and the Artic mutation. A transgenic line named tg- $\mathrm{APP}_{\text {Arcswe }}$ mice has been created under the control of the murine Thyl promoter. Strong intraneuronal $\mathrm{A} \beta$ immunostaining was observed at 2 months of age, which preceded plaque formation occurring at 5-6 months of age (Lord et al., 2006). Another mouse line named ArcA $\beta$ uses the murine prion protein promoter to express APP695 with the Swedish and Arctic mutations. These mice show intracellular $A \beta$ staining already at 3 months of age, with increasing amounts during aging. Interestingly, these mice develop age-dependent cognitive impairments, as shown by deficits in behavior tasks like the Y-maze or a two-way active avoidance paradigm (Knobloch et al., 2007b). Hippocampal LTP measurements disclosed a severe LTP impairment in young mice already at 3.5 and 7.5 months of age, which was obviously not due to developmental defects, as 1-month-old mice showed normal LTP and basal synaptic transmission. The mutations used in this model render $A \beta$ to be more prone to oligomer formation, which was held responsible for this effect as it could be reversed by a single dose of an antibody directed against the $\mathrm{A} \beta$ sequence administered to the animals $48 \mathrm{~h}$ before LTP induction (Knobloch et al., 2007a).

Recently a triple transgenic mouse model has been developed expressing both APP and Tau on a mutant PS1 knock-in background (3xTg-AD mice) (Oddo et al., 2003). Intracellular A $\beta$ is apparent between 3 and 4 months in these mice and precedes the deposition of extracellular $A \beta$ peptides starting around the age of 6 months. At this time point synaptic plasticity was already strongly compromised in these mice, as shown by impaired LTP (Oddo et al., 2003). Intracellular $A \beta$ accumulation is functionally linked to cognitive impairment in these mice, as they develop deficits in long-term retention at the age of 4 months, a time point prior to plaque deposition where only intracellular A $\beta$ is present (Billings et al., 2005). Morphological alterations of hippocampal synapses have been characterized in 13-month-old 3xTg-AD mice and age-matched PS1KI control mice. The numeric density of synapses, the average synaptic contact area, as well as the synaptic surface density were not altered, however, 3xTg-AD mice disclosed a significant decrease in the fraction of perforated synapses, which is believed to represent a reliable indirect index of synaptic plasticity (Bertoni-Freddari et al., 2008).

5XFAD mice express human APP with the Swedish, Florida (I716V) and London mutations, together with mutant PS1 (M146L, L286V) under the control of the murine Thyl promoter (Oakley et al., 2006). The earliest intracellular $A \beta$ accumulation could be detected at 1.5 months of age, immediately preceding extracellular plaque deposition occurring at the age of 2 months. The intraneuronal $\mathrm{A} \beta$ is in an aggregated state, as shown by Thioflavin-S staining and memory impairment, as shown by a reduced Y-maze performance and deficits in trace fear conditioning, compared to wildtype control animals, became evident already at the age of $4-5$ and 5-6 months respectively (Oakley et al., 2006; Ohno et al., 2007). Synaptic pathology in this model was demonstrated by reduced synaptophysin, syntaxin and PSD-95 levels in whole brain lysates. Synaptophysin levels start to decline already at 4 months of age and from 9 months on significantly reduced levels of syntaxin and PSD-95 were described (Oakley et al., 2006).

Early pathological changes like impaired synaptic transmission have been also reported in other transgenic AD mouse models, where intraneuronal $A \beta$ accumulation has not been reported. In APP transgenic mice harboring the Swedish and Indiana mutations under the control of the PGDF $\beta$-Promoter, deficits in synaptic transmission became evident prior to extracellular plaque formation. Without showing direct experimental evidence, the authors speculated that this might be due to neurotoxic effects possibly induced by intraneuronal $\mathrm{A} \beta$ accumulation or diffusible $\mathrm{A} \beta$ oligomers (Hsia et al., 1999). Another transgenic model, expressing APP with the London mutation, showed early behavioral changes, differential glutamate responses, as well as deficits in LTP, all occurring before extracellular plaque formation (Moechars et al., 1999). Finally, single APP (Swedish) and double APP (Swedish) and PS1 (M146L) transgenic mice were reported to show a reduced spontaneous alternation performance in the Y-maze task, before substantial extracellular plaque pathology became evident. The authors suggested that at least some aspects of the behavioral phenotype might be due to pathological alterations preceding plaque formation (Holcomb et al., 1999). In summary, we think that it would be worthwhile to examine the models with phenotypical changes prior to plaque formation on the occurrence of intraneuronal $A \beta$ aggregates.

\section{AD MOUSE MODELS WITH NEURON LOSS AND INTRANEURONAL A $\beta$ ACCUMULATION}

Despite of a plethora of transgenic AD mouse models expressing various APP isoforms and mutations, efforts modeling significant neuronal loss were, until recently, not successful (Irizarry et al., 1997a,b). First evidence for significant hippocampal neuron loss $(-14 \%)$, was reported in the APP23 mouse model, where the number of CA1 neurons was inversely correlated with CA1 plaque load (Calhoun et al., 1998).

Using unbiased stereologic methods, a loss of CA1-3 neurons in a magnitude of $\sim 30 \%$ was detected in 17 -month-old APP/PS1 transgenic mice, compared to age-matched PS1 control animals. Interestingly, the plaque load was approximately $10 \%$ smaller than the level of hippocampal pyramidal cell loss in these mice, indicating a loss of neurons at sites of $A \beta$ aggregation but additionally also distant from extracellular A $\beta$ deposits (Schmitz et al., 2004).

Another model showing massive hippocampal neuron loss is the abovementioned APP/PS1KI mouse model (Casas et al., 2004). At the age of 10 months an extensive neuron loss (>50\%) in the hippocampus was reported, that correlated with the accumulation of intraneuronal $A \beta$ and Thioflavin-S positive intracellular material and was already detectable at the age of 6 months (Casas et al., 2004). At this time point, a loss of $33 \%$ of CA1 pyramidal neurons compared to PS1KI littermates could be demonstrated (Figure 1G), together with decreased CA1 volume $(-30 \%)$ and an atrophy of the entire 
hippocampus of 18\% (Breyhan et al., 2009). A detailed stereological analysis of the frontal cortex revealed an early loss of cortical neurons starting at the age of 6 months which correlated with the transient intraneuronal $A \beta$ accumulation in contrast to extracellular plaque pathology (Christensen et al., 2008b). A related observation was made in distinct cholinergic brain stem nuclei $(\mathrm{Mo5}, 7 \mathrm{~N})$ in these mice, where neuronal loss at 6 or 12 months of age correlated with the presence of intraneuronal A $\beta$ peptides (Christensen et al., 2008a).

The 5XFAD mice underscore the potential influence of intraneuronal $A \beta$ accumulation on the loss of neurons. Cresyl violet staining revealed a reduced number of cortical layer 5 neurons, a region with robust intracellular $A \beta$ immunoreactivity. The same holds true for the subiculum where neurons where pale or entirely missing (Oakley et al., 2006). However, unbiased stereological neuron quantifications are needed to disclose the onset and severity of neuron loss in this model.

Recently, a new mouse model expressing only $\mathrm{N}$-truncated $\mathrm{A} \beta_{\mathrm{PE} 3-42}$ in neurons was generated and it was demonstrated for the first time that this peptide is neurotoxic in vivo inducing neuron loss and an associated neurological phenotype (Wirths et al., 2009).

\section{CONCLUSION}

In summary, there is accumulating evidence demonstrating that intraneuronal $\mathrm{A} \beta \mathrm{x}-42$ triggers early synaptic deficits and neuron loss. Extracellular $\mathrm{A} \beta$ deposition has been challenged in the past to

\section{REFERENCES}

Almeida, C. G., Tampellini, D., Takahashi, R. H., Greengard, P., Lin, M. T., Snyder, E. M., and Gouras, G. K. (2005). Beta-amyloid accumulation in APP mutant neurons reduces PSD-95 and GluR1 in synapses. Neurobiol. Dis. 20, 187-198.

Aoki, M., Volkmann, I., Tjernberg, L. O., Winblad, B., and Bogdanovic, N. (2008). Amyloid beta-peptide levels in laser capture microdissected cornu ammonis 1 pyramidal neurons of Alzheimer's brain. Neuroreport 19, 1085-1089.

Bahr, B. A., Hoffman, K. B., Yang, A. J., Hess, U. S., Glabe, C. G., and Lynch, G. (1998). Amyloid beta protein is internalized selectively by hippocampal field CAl and causes neurons to accumulate amyloidogenic carboxyterminal fragments of the amyloid precursor protein. J. Comp. Neurol. 397, 139-147.

Barghorn, S., Nimmrich, V., Striebinger, A., Krantz, C., Keller, P., Janson, B., Bahr, M., Schmidt, M., Bitner, R. S., Harlan, J., Barlow, E., Ebert, U., and Hillen, H. (2005). Globular amyloid beta-peptide oligomer - a homogenous and stable neuropathological protein in Alzheimer's disease. J. Neurochem. 31, 31.

Bayer, T.A., and Wirths, O. (2008). Review on the APP/PS1KI mouse model: intraneuronal Abeta accumulation triggers axonopathy, neuron loss and working memory impairment. Genes Brain Behav. 7(Suppl. 1), 6-11.

Bayer, T. A., Wirths, O., Majtenyi, K., Hartmann, T., Multhaup, G., Beyreuther, K., and Czech, C. (2001). Key factors in Alzheimer's disease: $\beta$ amyloid precursor protein processing, metabolism and intraneuronal transport. Brain Pathol. 11, 1-11.

Bertoni-Freddari, C., Sensi, S. L., Giorgetti, B., Balietti, M., Di Stefano, G., Canzoniero, L. M., Casoli, T., and Fattoretti, P. (2008). Decreased presence of perforated synapses in a triple-transgenic mouse model of Alzheimer's disease. Rejuvenation Res 11, 309-313.

Bi, X., Gall, C. M., Zhou, J., and Lynch, G. (2002). Uptake and pathogenic effects of amyloid beta peptide 1-42 are enhanced by integrin antagonists and blocked by NMDA receptor antagonists. Neuroscience 112, 827-840.

Billings, L. M., Oddo, S., Green, K. N., McGaugh, J. L., and Laferla, F. M. (2005). Intraneuronal Abeta causes the onset of early Alzheimer's diseaserelated cognitive deficits in transgenic mice. Neuron 45, 675-688.

Blanchard, V., Moussaoui, S., Czech, C., Touchet, N., Bonici, B., Planche, M., Canton, T., Jedidi, I., Gohin, M., Wirths, O., Bayer, T. A., Langui, D., Duyckaerts, C., Tremp, G., and Pradier, L. (2003). Time sequence of be a correlate for the striking region specific neuron loss, like the layer two pyramidal neurons in the entorhinal cortex and the CA1 neurons in the hippocampus (reviewed in Morrison and Hof, 1997). Among other interesting mouse models for AD, APP/PS1KI mice show early intraneuronal aggregation of full-length and $\mathrm{N}$-terminal modified $\mathrm{A} \beta \mathrm{x}-42$ peptides. Evidence has been demonstrated that these peptides are aggregated as shown by the OC antibody and Thioflavin-S staining. The time point of loss of LTP and disrupted PPF correlates with CA1 neuron loss, hippocampus atrophy and hippocampus-dependent deficits in learning and memory behavior in this model. This was accompanied by reduced levels of preand postsynaptic markers (Breyhan et al., 2009). A $\beta 42$ comprises $85 \%$ of the total $A \beta$ in this model, consisting of full-length and heterogeneous $\mathrm{N}$-terminal modified $\mathrm{A} \beta$ variants. The APP/PS1KI model is so far the model with the most aggressive pathology (Casas et al., 2004). Together with the data obtained from other transgenic mouse models, these data demonstrate that both synaptic deficits and neuron loss are a consequence of intraneuronal accumulation of $A \beta$ peptides.

\section{ACKNOWLEDGMENTS}

This work was supported by the Alzheimer Forschung Initiative e.V., Fritz Thyssen Foundation and the European Commission, Marie Curie Early Stage Training, MEST-CT-2005-020013 (NEURAD), Alzheimer Ph.D. Graduate School. maturation of dystrophic neurites associated with Abeta deposits in APP/PS1 transgenic mice. Exp. Neurol. 184, 247-263.

Braak, H., and Braak, E. (1991). Neuropathological stageing of Alzheimer-related changes. Acta Neuropathol. (Berl.) 82, 239-259.

Breyhan, H., Wirths, O., Duan, K., Marcello, A., Rettig, J., and Bayer, T. A. (2009). APP/PS1KI bigenic mice develop early synaptic deficits and hippocampus atrophy. Acta Neuropathol. 117, 677-685.

Busciglio, J., Pelsman, A., Wong, C., Pigino, G., Yuan, M., Mori, H., and Yankner, B. A. (2002). Altered metabolism of the amyloid beta precursor protein is associated with mitochondrial dysfunction in Down's syndrome. Neuron 33, 677-688.

Buxbaum, J. D., Liu, K. N., Luo, Y., Slack, J. L., Stocking, K. L., Peschon, J. J., Johnson, R. S., Castner, B. J., Cerretti, D. P., and Black, R. A. (1998). Evidence that tumor necrosis factor alpha converting enzyme is involved in regulated alpha-secretase cleavage of the Alzheimer amyloid protein precursor. J. Biol. Chem. 273, 27765-27767.

Calhoun, M. E., Wiederhold, K. H., Abramowski, D., Phinney,A.L., Probst, A., Sturchler-Pierrat, C., Staufenbiel, M., Sommer, B., and Jucker, M. (1998). Neuron loss in APP transgenic mice. Nature 395, 755-756.
Casas, C., Sergeant, N., Itier, J. M., Blanchard, V., Wirths, O., van der Kolk, N., Vingtdeux, V., van de Steeg, E., Ret, G., Canton, T., Drobecq, H., Clark, A., Bonici, B., Delacourte, A., Benavides, J., Schmitz, C., Tremp, G., Bayer, T. A., Benoit, P., and Pradier, L. (2004). Massive CA1/2 neuronal loss with intraneuronal and $\mathrm{N}$-terminal truncated Abeta42 accumulation in a novel Alzheimer transgenic model. Am. J. Pathol. 165, 1289-1300.

Caspersen, C., Wang, N., Yao, J., Sosunov, A., Chen, X., Lustbader, J. W., Xu, H. W., Stern, D., McKhann, G., and Yan, S. D. (2005). Mitochondrial Abeta: a potential focal point for neuronal metabolic dysfunction in Alzheimer's disease. FASEB J. 19, 2040-2041.

Christensen, D. Z., Bayer, T. A., and Wirths, O. (2008a). Intracellular Abeta triggers neuron loss in the cholinergic system of the APP/ PS1KI mouse model of Alzheimer's disease. Neurobiol. Aging. doi 1016/j.neurobiolaging.2008.07.022.

Christensen, D. Z., Kraus, S. L., Flohr, A., Cotel, M. C., Wirths, O., and Bayer, T. A. (2008b). Transient intraneuronal Abeta rather than extracellular plaque pathology correlates with neuron loss in the frontal cortex of APP/PS1KI mice. Acta Neuropathol. 116, 647-655.

Chui, D. H., Tanahashi, H., Ozawa, K., Ikeda, S., Checler, F., Ueda, O., Suzuki, 
H., Araki, W., Inoue, H., Shirotani, K., Takahashi, K., Gallyas, F., and Tabira, T. (1999). Transgenic mice with Alzheimer presenilin 1 mutations show accelerated neurodegeneration without amyloid plaque formation. Nat. Med. 5, 560-564.

D’Andrea, M. R., Nagele, R. G., Gumula, N. A., Reiser, P. A., Polkovitch, D. A., Hertzog, B. M., and Andrade-Gordon, P. (2002). Lipofuscin and Abeta42 exhibit distinct distribution patterns in normal and Alzheimer's disease brains. Neurosci. Lett. 323, 45-49.

D’Andrea, M. R., Nagele, R. G., Wang, H. Y., Peterson, P. A., and Lee, D. H. (2001). Evidence that neurones accumulating amyloid can undergo lysis to form amyloid plaques in Alzheimer's disease. Histopathology 38, 120-134.

D'Andrea, M. R., Reiser, P. A., Polkovitch, D. A., Gumula, N. A., Branchide, B., Hertzog, B. M., Schmidheiser, D., Belkowski, S., Gastard, M. C., and Andrade-Gordon, P. (2003). The use of formic acid to embellish amyloid plaque detection in Alzheimer's disease tissues misguides key observations. Neurosci. Lett. 342, 114-118.

De Felice, F. G., Velasco, P. T., Lambert, M. P., Viola, K., Fernandez, S. J., Ferreira, S. T., and Klein, W. L. (2007). Abeta oligomers induce neuronal oxidative stress through an N-methyl-D-aspartate receptor-dependent mechanism that is blocked by the Alzheimer drug memantine. J. Biol. Chem. 282, 11590-11601.

Ditaranto, K., Tekirian, T. L., and Yang, A. J. (2001). Lysosomal membrane damage in soluble Abeta-mediated cell death in Alzheimer's disease. Neurobiol. Dis. 8, 19-31.

Dong, H., Martin, M. V., Chambers, S., and Csernansky, J. G. (2007). Spatial relationship between synapse loss and beta-amyloid deposition in Tg2576 mice. J. Comp. Neurol. 500, 311-321.

Duyckaerts, C., Potier, M. C., and Delatour, B. (2008). Alzheimer disease models and human neuropathology: similarities and differences. Acta Neuropathol. $115,5-38$.

Dziewczapolski, G., Glogowski, C. M., Masliah, E., and Heinemann, S. F. (2009). Deletion of the alpha 7 nicotinic acetylcholine receptor gene improves cognitive deficits and synaptic pathology in a mouse model of Alzheimer's disease. J. Neurosci. 29, 8805-8815.

Eckert, A., Hauptmann, S., Scherping, I., Rhein, V., Muller-Spahn, F., Gotz, J., and Muller, W. E. (2008). Soluble beta-amyloid leads to mitochondrial defects in amyloid precursor protein and tau transgenic mice. Neurodegener. Dis. 5, 157-159.

Fernandez-Vizarra, P., Fernandez, A. P., Castro-Blanco, S., Serrano, J., Bentura,
M.L., Martinez-Murillo, R., Martinez, A., Rodrigo, J., Encinas, J. M., Munoz, P., Alonso, D., Gomez, M. B., Sanchez, J., Rios-Tejada, F., Salas, E., Lisazoain, I., Leza, J. C., Lopez, J. C., Manuel Encinas, J., Lorenzo, P., Pedrosa, J. A., Peinado, M.A., Richart, A., Santacana, M., Cuttitta, F., Uttenthal, L. O., Bosca, L., Rodriguez, I., and Ruiz-Cabello, J. (2004). Intra- and extracellular Abeta and PHF in clinically evaluated cases of Alzheimer's disease. Histol. Histopathol. 19, 823-844.

Games, D., Buttini, M., Kobayashi, D., Schenk, D., and Seubert, P. (2006). Mice as models: transgenic approaches and Alzheimer's disease. J. Alzheimers Dis. 9(Suppl.), 133-149.

Gong, Y., Chang, L., Viola, K. L., Lacor, P. N., Lambert, M. P., Finch, C. E., Krafft, G. A., and Klein, W. L. (2003). Alzheimer's disease-affected brain: presence of oligomeric A beta ligands (ADDLs) suggests a molecular basis for reversible memory loss. Proc. Natl. Acad. Sci. U.S.A. 100, 10417-10422.

Gouras, G. K., Tsai, J., Naslund, J., Vincent, B., Edgar, M., Checler, F., Greenfield, J. P., Haroutunian, V., Buxbaum, J. D., Xu, H., Greengard, P., and Relkin, N. R. (2000). Intraneuronal Abeta42 accumulation in human brain. Am. J. Pathol. 156, 15-20.

Grundke-Iqbal, I., Iqbal, K., George, L., Tung, Y.C., Kim, K. S., and Wisniewski, H. M. (1989). Amyloid protein and neurofibrillary tangles coexist in the same neuron in Alzheimer disease. Proc. Natl. Acad. Sci. U.S.A. 86, 2853-2857.

Gyure, K. A., Durham, R., Stewart, W. F., Smialek, J. E., and Troncoso, J. C. (2001). Intraneuronal abeta-amyloid precedes development of amyloid plaques in Down syndrome. Arch. Pathol. Lab. Med. 125, 489-492.

Hansson Petersen, C. A., Alikhani, N., Behbahani, H., Wiehager, B., Pavlov, P. F., Alafuzoff, I., Leinonen, V., Ito, A., Winblad, B., Glaser, E., and Ankarcrona, M. (2008). The amyloid beta-peptide is imported into mitochondria via the TOM import machinery and localized to mitochondrial cristae. Proc. Natl. Acad. Sci. U.S.A. 105, 13145-13150.

Hardy, J., and Allsop, D. (1991). Amyloid deposition as the central event in the aetiology of Alzheimer's disease. Trends Pharmacol. Sci. 12, 383-388.

Hardy, J., and Selkoe, D. J. (2002). The amyloid hypothesis of Alzheimer's disease: progress and problems on the road to therapeutics. Science 297, 353-356.

Holcomb, L. A., Gordon, M. N., Jantzen, P., Hsiao, K., Duff, K., and Morgan, D. (1999). Behavioral changes in transgenic mice expressing both amyloid precursor protein and presenilin-1 mutations: lack of association with amyloid deposits. Behav. Genet. 29, 177-185.

Hsia, A. Y., Masliah, E., McConlogue, L., Yu, G. Q., Tatsuno, G., Hu, K., Kholodenko, D., Malenka, R. C., Nicoll, R. A., and Mucke, L. (1999). Plaque-independent disruption of neural circuits in Alzheimer's disease mouse models. Proc. Natl. Acad. Sci. U.S.A. 96, 3228-3233.

Hussain, I., Powell, D., Howlett, D. R., Tew, D. G., Meek, T. D., Chapman, C., Gloger, I. S., Murphy, K. E., Southan, C. D., Ryan, D. M., Smith, T.S., Simmons, D. L., Walsh, F. S., Dingwall, C., and Christie, G. (1999). Identification of a novel aspartic protease (Asp 2) as beta-secretase. Mol. Cell. Neurosci. 14, 419-427.

Irizarry, M.C., McNamara, M., Fedorchak, K., Hsiao, K., and Hyman, B. T. (1997a). APPSw transgenic mice develop agerelated A beta deposits and neuropil abnormalities, but no neuronal loss in CA1. J. Neuropathol. Exp. Neurol. 56, 965-973.

Irizarry, M. C., Soriano, F., McNamara, M., Page, K. J., Schenk, D., Games, D., and Hyman, B. T. (1997b). Abeta deposition is associated with neuropil changes, but not with overt neuronal loss in the human amyloid precursor protein V717F (PDAPP) transgenic mouse. J. Neurosci. 17, 7053-7059.

Kamenetz, F., Tomita, T., Hsieh, H., Seabrook, G., Borchelt, D., Iwatsubo, T., Sisodia, S., and Malinow, R. (2003). APP processing and synaptic function. Neuron 37, 925-937.

Klein, W. L. (2002). Abeta toxicity in Alzheimer's disease: globular oligomers (ADDLs) as new vaccine and drug targets. Neurochem. Int. 41, 345-352.

Klein, W. L., Krafft, G. A., and Finch, C. E. (2001). Targeting small Abeta oligomers: the solution to an Alzheimer's disease conundrum? Trends Neurosci. 24, 219-224.

Knauer, M. F., Soreghan, B., Burdick, D., Kosmoski, J., and Glabe, C. G. (1992). Intracellular accumulation and resistance to degradation of the Alzheimer amyloid A4/beta protein. Proc. Natl. Acad. Sci. U.S.A. 89 , 7437-7441.

Knobloch, M., Farinelli, M., Konietzko, U., Nitsch, R.M., and Mansuy, I.M. (2007a). Abeta oligomer-mediated long-term potentiation impairment involves protein phosphatase 1-dependent mechanisms. J. Neurosci. 27, 7648-7653.

Knobloch, M., Konietzko, U., Krebs, D. C., and Nitsch, R.M.(2007b). Intracellular Abeta and cognitive deficits precede beta-amyloid deposition in transgenic arcAbeta mice. Neurobiol. Aging 28, 1297-1306.
Kumar-Singh, S., De Jonghe, C., Cruts, M., Kleinert, R., Wang, R., Mercken, M., De Strooper, B., Vanderstichele, H., Lofgren, A., Vanderhoeven, I., Backhovens, H., Vanmechelen, E., Kroisel, P. M., and Van Broeckhoven, C. (2000). Nonfibrillar diffuse amyloid deposition due to a gamma(42)secretase site mutation points to an essential role for $\mathrm{N}$-truncated A beta(42) in Alzheimer's disease. Hum. Mol. Genet. 9, 2589-2598.

Lacor, P. N., Buniel, M. C., Chang, L., Fernandez, S. J., Gong, Y., Viola, K. L., Lambert, M. P., Velasco, P. T., Bigio, E. H., Finch, C. E., Krafft, G. A., and Klein, W. L. (2004). Synaptic targeting by Alzheimer's-related amyloid beta oligomers. J. Neurosci. 24, 10191-10200.

Lacor, P. N., Buniel, M. C., Furlow, P. W., Clemente, A. S., Velasco, P. T., Wood, M., Viola, K. L., and Klein, W. L. (2007).Abeta oligomer-induced aberrations in synapse composition, shape, and density provide a molecular basis for loss of connectivity in Alzheimer's disease. J. Neurosci. 27, 796-807.

Lambert, M. P., Barlow, A. K., Chromy, B. A., Edwards, C., Freed, R., Liosatos, M., Morgan, T. E., Rozovsky, I., Trommer, B., Viola, K. L., Wals, P., Zhang, C., Finch, C. E., Krafft, G. A., and Klein, W. L. (1998). Diffusible, nonfibrillar ligands derived from Abeta 1-42 are potent central nervous system neurotoxins. Proc. Natl. Acad. Sci. U.S.A. 95, 6448-6453.

Lammich, S., Kojro, E., Postina, R., Gilbert, S., Pfeiffer, R., Jasionowski, M., Haass, C., and Fahrenholz, F. (1999). Constitutive and regulated alphasecretase cleavage of Alzheimer's amyloid precursor protein by a disintegrin metalloprotease. Proc. Natl. Acad. Sci. U.S.A. 96, 3922-3927.

Langui, D., Girardot, N., El Hachimi, K. H., Allinquant, B., Blanchard, V., Pradier, L., and Duyckaerts, C. (2004). Subcellular topography of neuronal Abeta peptide in APPxPS1 transgenic mice. Am. J. Pathol. 165, 1465-1477.

Li, M., Chen, L., Lee, D. H., Yu, L. C., and Zhang, Y. (2007). The role of intracellular amyloid beta in Alzheimer's disease. Prog. Neurobiol. 83, 131-139.

Lord, A., Kalimo, H., Eckman, C., Zhang, X. Q., Lannfelt, L., and Nilsson, L. N. (2006). The Arctic Alzheimer mutation facilitates early intraneuronal Abeta aggregation and senile plaque formation in transgenic mice. Neurobiol. Aging 27, 67-77.

Lue, L. F., Kuo, Y.M., Roher,A.E., Brachova, L., Shen, Y., Sue, L., Beach, T., Kurth, J. H., Rydel, R. E., and Rogers, J. (1999). Soluble amyloid beta peptide concentration as a predictor of synaptic 
change in Alzheimer's disease. Am. J. Pathol. 155, 853-862.

Lustbader, J. W., Cirilli, M., Lin, C., Xu, H. W., Takuma, K., Wang, N., Caspersen, C., Chen, X., Pollak, S., Chaney, M., Trinchese, F., Liu, S., Gunn-Moore, F., Lue, L. F., Walker, D. G., Kuppusamy, P., Zewier, Z. L., Arancio, O., Stern, D., Yan, S. S., and Wu, H. (2004). ABAD directly links Abeta to mitochondrial toxicity in Alzheimer's disease. Science 304, 448-452.

Manczak, M.,Anekonda, T. S., Henson, E., Park, B. S., Quinn, J., and Reddy, P. H. (2006). Mitochondria are a direct site of A beta accumulation in Alzheimer's disease neurons: implications for free radical generation and oxidative damage in disease progression. Hum. Mol. Genet. 15, 1437-1449.

Masliah, E., Mallory, M., Alford, M., DeTeresa, R., Hansen, L. A., McKeel, D. W. Jr., and Morris, J. C. (2001). Altered expression of synaptic proteins occurs early during progression of Alzheimer's disease. Neurology 56, 127-129.

Masliah, E., Mallory, M., Hansen, L., DeTeresa, R., Alford, M., and Terry, R. (1994). Synaptic and neuritic alterations during the progression of Alzheimer's disease. Neurosci. Lett. 174, 67-72.

Masters, C. L., Multhaup, G., Simms, G., Pottgiesser, J., Martins, R. N., and Beyreuther, K. (1985). Neuronal origin of a cerebral amyloid: neurofibrillary tangles of Alzheimer's disease contain the same protein as the amyloid of plaque cores and blood vessels. $E M B O$ J. 4, 2757-2763.

McLean, C. A., Cherny, R. A., Fraser, F.W., Fuller, S. J., Smith, M. J., Beyreuther, K., Bush, A. I., and Masters, C. L. (1999). Soluble pool of Abeta amyloid as a determinant of severity of neurodegeneration in Alzheimer's disease. Ann. Neurol. 46, 860-866.

Mochizuki, A., Tamaoka, A., Shimohata, A., Komatsuzaki, Y., and Shoji, S. (2000). Abeta42-positive nonpyramidal neurons around amyloid plaques in Alzheimer's disease [letter]. Lancet 355, 42-43.

Moechars, D., Dewachter, I., Lorent, K., Reverse, D., Baekelandt, V., Naidu, A., Tesseur, I., Spittaels, K., Haute, C. V., Checler, F., Godaux, E., Cordell, B., and Van Leuven, F. (1999). Early phenotypic changes in transgenic mice that overexpress different mutants of amyloid precursor protein in brain. $J$. Biol. Chem. 274, 6483-6492.

Mori, C., Spooner, E. T., Wisniewsk, K. E., Wisniewski, T.M.,Yamaguch, H., Saido, T. C., Tolan, D. R., Selkoe, D. J., and Lemere, C. A. (2002). Intraneuronal Abeta42 accumulation in Down syndrome brain. Amyloid 9, 88-102.
Morrison, J. H., and Hof, P. R. (1997). Life and death of neurons in the aging brain. Science 278, 412-419.

Nagele, R. G., D'Andrea, M. R., Anderson, W. J., and Wang, H. Y. (2002). Intracellular accumulation of betaamyloid(1-42) in neurons is facilitated by the alpha 7 nicotinic acetylcholine receptor in Alzheimer's disease. Neuroscience 110, 199-211.

Naslund, J., Haroutunian, V., Mohs, R., Davis, K. L., Davies, P., Greengard, P., and Buxbaum, J.D. (2000). Correlation between elevated levels of amyloid beta-peptide in the brain and cognitive decline. JAMA 283, 1571-1577.

Nilsberth, C., Westlind-Danielsson, A., Eckman, C. B., Condron, M. M., Axelman, K., Forsell, C., Stenh, C., Luthman, J., Teplow, D. B., Younkin, S. G., Naslund, J., and Lannfelt, L. (2001). The 'Arctic' APP mutation (E693G) causes Alzheimer's disease by enhanced Abeta protofibril formation. Nat. Neurosci. 4, 887-893.

Nimmrich, V., Grimm, C., Draguhn, A., Barghorn,S.,Lehmann,A.,Schoemaker, H., Hillen, H., Gross, G., Ebert, U., and Bruehl, C. (2008). Amyloid \{beta $\}$ oligomers (A $\{$ beta $\}$ 1-42 globulomer) suppress spontaneous synaptic activity by inhibition of P/Q-type calcium currents. J. Neurosci. 28, 788-797.

Oakley, H., Cole, S. L., Logan, S., Maus, E., Shao, P., Craft, J., GuillozetBongaarts, A., Ohno, M., Disterhoft, J., Van Eldik, L., Berry, R., and Vassar, R. (2006). Intraneuronal beta-amyloid aggregates, neurodegeneration, and neuron loss in transgenic mice with five familial Alzheimer's disease mutations: potential factors in amyloid plaque formation. J. Neurosci. 26, 10129-10140.

Oddo, S., Caccamo, A., Shepherd, J. D., Murphy, M. P., Golde, T. E., Kayed, R., Metherate, R., Mattson, M. P., Akbari, Y., and LaFerla, F. M. (2003). Tripletransgenic model of Alzheimer's disease with plaques and tangles: intracellular Abeta and synaptic dysfunction. Neuron 39, 409-421.

Ohno, M., Cole, S. L., Yasvoina, M., Zhao, J., Citron, M., Berry, R., Disterhoft, J. F., and Vassar, R. (2007). BACE1 gene deletion prevents neuron loss and memory deficits in 5XFAD APP/PS1 transgenic mice. Neurobiol. Dis. 26, 134-145.

Ohyagi, Y., Tsuruta, Y., Motomura, K., Miyoshi, K., Kikuchi, H., Iwaki, T., Taniwaki, T., and Kira, J. (2007). Intraneuronal amyloid beta 42 enhanced by heating but counteracted by formic acid. J. Neurosci. Methods 159, 134-138.

Reddy, P. H., and Beal, M. F. (2008). Amyloid beta, mitochondrial dysfunction and synaptic damage: implications for cognitive decline in aging and Alzheimer's disease. Trends. Mol. Med. 14, 45-53.

Roychaudhuri, R., Yang, M., Hoshi, M. M., and Teplow, D. B. (2009). Amyloid beta-protein assembly and Alzheimer disease. J. Biol. Chem. 284, 4749-4753.

Rui, Y., Tiwari, P., Xie, Z., and Zheng, J. Q. (2006). Acute impairment of mitochondrial trafficking by beta-amyloid peptides in hippocampal neurons. $J$. Neurosci. 26, 10480-10487.

Rutten, B. P., Van der Kolk, N. M., Schafer, S., van Zandvoort, M. A., Bayer, T. A., Steinbusch, H. W., and Schmitz, C. (2005). Age-related loss of synaptophysin immunoreactive presynaptic boutons within the hippocampus of APP751SL, PS1M146L, and APP751SL/PS1M146L transgenic mice. Am. J. Pathol. 167, 161-173.

Scheff, S. W., Price, D. A., Schmitt, F. A., DeKosky, S. T., and Mufson, E. J. (2007). Synaptic alterations in CA1 in mild Alzheimer disease and mild cognitive impairment. Neurology 68 , 1501-1508.

Schmitz, C., Rutten, B. P., Pielen, A., Schafer, S., Wirths, O., Tremp, G., Czech, C., Blanchard, V., Multhaup G., Rezaie, P., Korr, H., Steinbusch, H. W., Pradier, L., and Bayer, T. A. (2004) Hippocampal neuron loss exceeds amyloid plaque load in a transgenic mouse model of Alzheimer's disease. Am. J. Pathol. 164, 1495-1502.

Selkoe, D. J., and Wolfe, M. S. (2007). Presenilin: running with scissors in the membrane. Cell 131, 215-221.

Sinha, S., Anderson, J.P., Barbour, R., Basi, G. S., Caccavello, R., Davis, D., Doan, M., Dovey, H. F., Frigon, N., Hong, J., Jacobson-Croak, K., Jewett, N., Keim, P., Knops, J., Lieberburg, I., Power, M., Tan, H., Tatsuno, G., Tung, J., Schenk, D., Seubert, P., Suomensaari, S. M. Wang, S., Walker, D., John, V. (1999). Purification and cloning of amyloid precursor protein beta-secretase from human brain. Nature 402, 537-540.

Takahashi, R. H., Almeida, C. G., Kearney, P. F., Yu, F., Lin, M. T., Milner, T.A., and Gouras, G. K. (2004). Oligomerization of Alzheimer's beta-amyloid within processes and synapses of cultured neurons and brain. J. Neurosci. 24, 3592-3599.

Takahashi, R. H., Milner, T. A., Li, F., Nam, E. E., Edgar, M. A., Yamaguchi, H., Beal, M. F., Xu, H., Greengard, P., and Gouras, G. K. (2002). Intraneuronal Alzheimer abeta 42 accumulates in multivesicular bodies and is associated with synaptic pathology. Am. J. Pathol. 161, 1869-1879.

Takuma, K., Fang, F., Zhang, W., Yan, S., Fukuzaki, E., Du, H., Sosunov, A., McKhann, G., Funatsu, Y., Nakamichi,
N.,Nagai, T.,Mizoguchi,H.,Ibi,D.,Hori, O., Ogawa, S., Stern, D. M., Yamada, K., and Yan, S. S. (2009). RAGE-mediated signaling contributes to intraneuronal transport of amyloid-beta and neuronal dysfunction. Proc. Natl. Acad. Sci. U.S.A. 106, 20021-20026.

Terry, R. D., Masliah, E., Salmon, D. P., Butters, N., DeTeresa, R., Hill, R. Hansen, L.A., and Katzman, R. (1991). Physical basis of cognitive alterations in Alzheimer's disease: synapse loss is the major correlate of cognitive impairment. Ann. Neurol. 30, 572-580.

Van Broeck, B., Vanhoutte, G., Pirici, D., Van Dam, D., Wils, H., Cuijt, I., Vennekens, K.,Zabielski, M., Michalik, A., Theuns, J., De Deyn, P. P., Van der Linden, A., Van Broeckhoven, C., and Kumar-Singh, S. (2008). Intraneuronal amyloid beta and reduced brain volume in a novel APP T714I mouse model for Alzheimer's disease. Neurobiol. Aging 29, 241-252.

Vassar, R., Bennett, B. D., Babu-Khan, S., Kahn, S., Mendiaz, E. A., Denis, P., Teplow, D. B., Ross, S., Amarante, P., Loeloff, R., Luo, Y., Fisher, S., Fuller, J., Edenson, S., Lile, J., Jarosinski, M. A., Biere, A. L., Curran, E., Burgess, T., Louis, J. C., Collins, F., Treanor, J., Rogers, G., and Citron, M. (1999). Beta-secretase cleavage of Alzheimer's amyloid precursor protein by the transmembrane aspartic protease BACE. Science 286, 735-741.

Walsh, D. M., Klyubin, I., Fadeeva, J. V., Cullen, W. K., Anwyl, R., Wolfe, M. S., Rowan, M. J., and Selkoe, D. J. (2002). Naturally secreted oligomers of amyloid beta protein potently inhibit hippocampal long-term potentiation in vivo. Nature 416, 535-539.

Walsh, D. M., Tseng, B. P., Rydel, R. E., Podlisny, M. B., and Selkoe, D. J. (2000). The oligomerization of amyloid beta-protein begins intracellularly in cells derived from human brain. Biochemistry 39, 10831-10839.

Wang, H. Y., Lee, D. H., D’Andrea, M. R., Peterson, P. A., Shank, R. P., and Reitz, A. B. (2000). beta-Amyloid(1-42) binds to alpha7 nicotinic acetylcholine receptor with high affinity. Implications for Alzheimer's disease pathology. J. Biol. Chem. 275, 5626-5632.

Wegiel, J., Kuchna, I., Nowicki, K., Frackowiak, J., Mazur-Kolecka, B., Imaki, H., Wegiel, J., Mehta, P. D., Silverman, W. P., Reisberg, B., Deleon, M., Wisniewski, T., Pirttilla, T., Frey, H., Lehtimaki, T., Kivimaki, T., Visser, F. E., Kamphorst, W., Potempska, A., Bolton, D., Currie, J. R., and Miller, D. L. (2007). Intraneuronal Abeta immunoreactivity is not a predictor of brain amyloidosis-beta or neurofibrillary degeneration. Acta Neuropathol. (Berl.) 113, 389-402. 
Wirths, O., Breyhan, H., Cynis, H., Schilling, S., Demuth, H. U., and Bayer, T. A. (2009). Intraneuronal pyroglutamate-Abeta 3-42 triggers neurodegeneration and lethal neurological deficits in a transgenic mouse model. Acta Neuropathol. 487-496.

Wirths, O., Breyhan, H., Schafer, S., Roth, C., and Bayer, T. A. (2008). Deficits in working memory and motor performance in the APP/PS1ki mouse model for Alzheimer's disease. Neurobiol. Aging 29, 891-901.

Wirths, O., Multhaup, G., and Bayer, T. A. (2004). A modified beta-amyloid hypothesis: intraneuronal accumulation of the beta-amyloid peptide the first step of a fatal cascade. $J$. Neurochem. 91, 513-520.

Wirths, O., Multhaup, G., Czech, C., Blanchard, V., Moussaoui, S., Tremp, G., Pradier, L., Beyreuther, K., and Bayer, T. A. (2001). Intraneuronal Abeta accumulation precedes plaque formation in beta-amyloid precursor protein and presenilin-1 doubletransgenic mice. Neurosci. Lett. 306, 116-120.

Wirths, O., Multhaup, G., Czech, C., Feldmann, N., Blanchard, V., Tremp, G., Beyreuther, K., Pradier, L., and Bayer, T. A. (2002). Intraneuronal APP/A beta trafficking and plaque formation in beta-amyloid precursor protein and presenilin-1 transgenic mice. Brain Pathol. 12, 275-286.

Wirths, O., Weis, J., Kayed, R., Saido, T. C., and Bayer, T.A. (2007). Age-dependent axonal degeneration in an Alzheimer mouse model. Neurobiol. Aging 28, 1689-1699.

Wolfe, M. S. (2007). When loss is gain: reduced presenilin proteolytic function leads to increased Abeta42/ Abeta40. Talking Point on the role of presenilin mutations in Alzheimer disease. EMBO Rep. 8, 136-140.
Yan, R., Bienkowski, M. J., Shuck, M. E., Miao, H., Tory, M. C., Pauley, A. M., Brashier, J. R., Stratman, N. C., Mathews, W. R., Buhl, A. E., Carter, D. B., Tomasselli, A. G., Parodi, L. A., Heinrikson, R. L., and Gurney, M. E. (1999). Membrane-anchored aspartyl protease with Alzheimer's disease beta-secretase activity. Nature 402, 533-537.

Yang, A. J., Chandswangbhuvana, D., Margol, L., and Glabe, C. G. (1998). Loss of endosomal/lysosomal membrane impermeability is an early event in amyloid Abeta 1-42 pathogenesis. J. Neurosci. Res. 2, 691-698.

Zhao, X. L., Wang, W.A., Tan, J.X., Huang, J. K., Zhang, X., Zhang, B. Z., Wang, Y. H., Yangcheng, H. Y., Zhu, H. L., Sun, X. J., and Huang, F. D. (2010). Expression of $\{$ beta $\}$-amyloid induced age-dependent presynaptic and axonal changes in Drosophila. J. Neurosci. 30, 1512-1522.
Conflict of Interest Statement: The authors declare that the research was conducted in the absence of any commercial or financial relationships that could be construed as a potential conflict of interest.

Received: 22 January 2010; paper pending published: 06 February 2010; accepted: 12 February 2010; published online: 10 March 2010.

Citation: Bayer TA and Wirths O (2010) Intracellular accumulation of amyloidbeta - a predictor for synaptic dysfunction and neuron loss in Alzheimer's disease. Front. Ag. Neurosci. 2:8. doi: 10.3389/fnagi.2010.00008

Copyright $\odot 2010$ Bayer and Wirths. This is an open-access article subject to an exclusive license agreement between the authors and the Frontiers Research Foundation, which permits unrestricted use, distribution, and reproduction in any medium, provided the original authors and source are credited. 